\title{
66 COMBINING CHEMICAL AND X-RAY MICROTOMOGRAPHY INVESTIGATIONS ON CRUSTAL XENOLITHS AT MOUNT ETNA: EVIDENCE OF VOLCANIC GAS FLUXING,
}

\author{
Gabriele Lanzafame* ${ }^{*}$, Carmelo Ferlito ${ }^{2}$, Sandro Donato ${ }^{3,4}$ \\ (1) Elettra-Sincrotrone Trieste S.C.p.A., Basovizza (Trieste), Italy \\ (2) Dipartimento di Scienze Biologiche, Geologiche e Ambientali, Università di Catania, Catania, Italy \\ (3) Dipartimento di Fisica, Università di Trieste, Trieste, Italy \\ (4) INFN - Sezione di Trieste, Trieste, Italy
}

Article history

Receveid April 19, 2018; accepted October 4, 2018.

Subject classification:

Xenoliths; X-Ray microtomography; Mount Etna; Gas fluxing; Alkali Enrichment.

\begin{abstract}
Crustal xenoliths embedded in lavas offer chances to provide information on the lithology of the volcano basement and the process occurring during magma ascent. In this work we studied seven xenoliths found among the scoriae ejected during several paroxysms occurred between 2011 and 2016 at the South East Crater (SEC) of Mount Etna volcano. These samples are characterized by massive presence of glass and vesicles resulting in a foam-like appearance of their texture. A detailed study of their textural and chemical features was carried out combining XRF, SEM-EDS, two-dimensional observation and Synchrotron X-ray microtomography (3D imaging). This multidisciplinary approach allowed us to identify and quantify the components of the samples, individuate the likely provenance rock, ascribable to the Numidian Flysch outcropping west of the Etnean edifice. 2D and 3D imaging were successfully applied to estimate the amount of the phases constituting the samples (grains + glass + vesicles) and the degree of partial melting that occurred during the interaction with the basaltic melt and gaseous phase. The sedimentary xenoliths underwent profound textural and geochemical changes led by partial melting, vesiculation and selective alkali enrichment. These processes could not be driven exclusively by the prolonged contact with the molten phase, but could be considered as resulting of a significant gas fluxing of the volatiles rising through the plumbing system and the sedimentary basement.
\end{abstract}

\section{INTRODUCTION}

In the last three decades attention for xenoliths of Mount Etna volcano (Sicily, Italy) has raised following the discovery of sedimentary-like rocks enclaves in historic lavas [Ferla et al., 1978; Michaud, 1995] and due to the occurrence of many quartzarenitic fragments during the eruptive events of 2001 and 20022003 [Monaco et al., 2005; Ferlito et al., 2008; 2009]. These sedimentary xenoliths were embedded in lava flows emitted by the eruptive vents of the N-S rift [Behncke and Neri, 2003; Clocchiatti et al., 2004; Allard et al., 2006; Viccaro et al., 2006; Corsaro et al., 2007] or fragmented during explosive activity. More recently, xenoliths have been ejected together with scoriae during the short and violent paroxysms that occurred at the South East Crater (SEC) [Mollo et al., 2017]. Besides the information that Etnean xenoliths have provided on the basement beneath the volcanic edifice, attention has been drawn to the hints that they might offer on the 
processes affecting magma ascent, including host-rock assimilation. This has been considered by some authors as able to modify the chemical composition of the magmas rising to the surface, thus to produce significant variability among the erupted products. In particular, the relevance of assimilation has been proposed to justify and explain the increase in $\mathrm{K}$ and other LILE of the trachybasaltic lavas emitted after the 1971 eruption [Joron and Treuil, 1984; Clocchiatti et al., 1988; Marty et al., 1994; Condomines et al., 1995; Michaud, 1995; Tonarini et al., 1995; Tanguy et al., 1997]. Therefore, these peculiar and rare samples on one hand provide information about the sedimentary basement laying beneath the volcanic edifice, and on the other hand interact with the magmas in which they are embedded, undergoing textural and chemical modifications that can be used to understand the petrological processes occurring within the plumbing system.

A profitable occasion to return to the Etnean xenoliths was offered by the finding of seven xenoliths embedded in the products erupted during the paroxysm that occurred from 2011 to 2016 at Mount Etna. These samples show intriguing chemical and petrographic characters, indicating a different origin (e.g. provenance from varied parental rock) and history in terms of textural and compositional modifications that occurred during the transport through the volcano feeding system by the rising magmas. A detailed study was carried out on all the samples combining the common methods employed in petrography and petrology (XRay Fluorescence, optical observation on thin sections and SEM-EDS analysis) with Synchrotron Radiation XRay computed microtomography ( $\mathrm{SR} \mu \mathrm{CT}$ ). The choice of using different techniques arises from the nature of the samples, showing peculiar textures characterized by the presence of mineral grains in highly vesiculated glass, giving some of the xenoliths a friable foam-like appearance (Figure 1). Such textures pose an interrogative on what is the best way to accurately represent and investigate their structure and quantify their components. In fact, rocks containing large-sized vesicles and grains dispersed in three-dimensions are difficult to be exhaustively represented by the bi-dimensional constrains of thin sections. Moreover, because of their fragility and rarity, a non-destructive imaging technique is essential to preserve samples for further analysis. These requirements are all matched by microtomography techniques, that have been recently and successfully employed in multiscale studies of

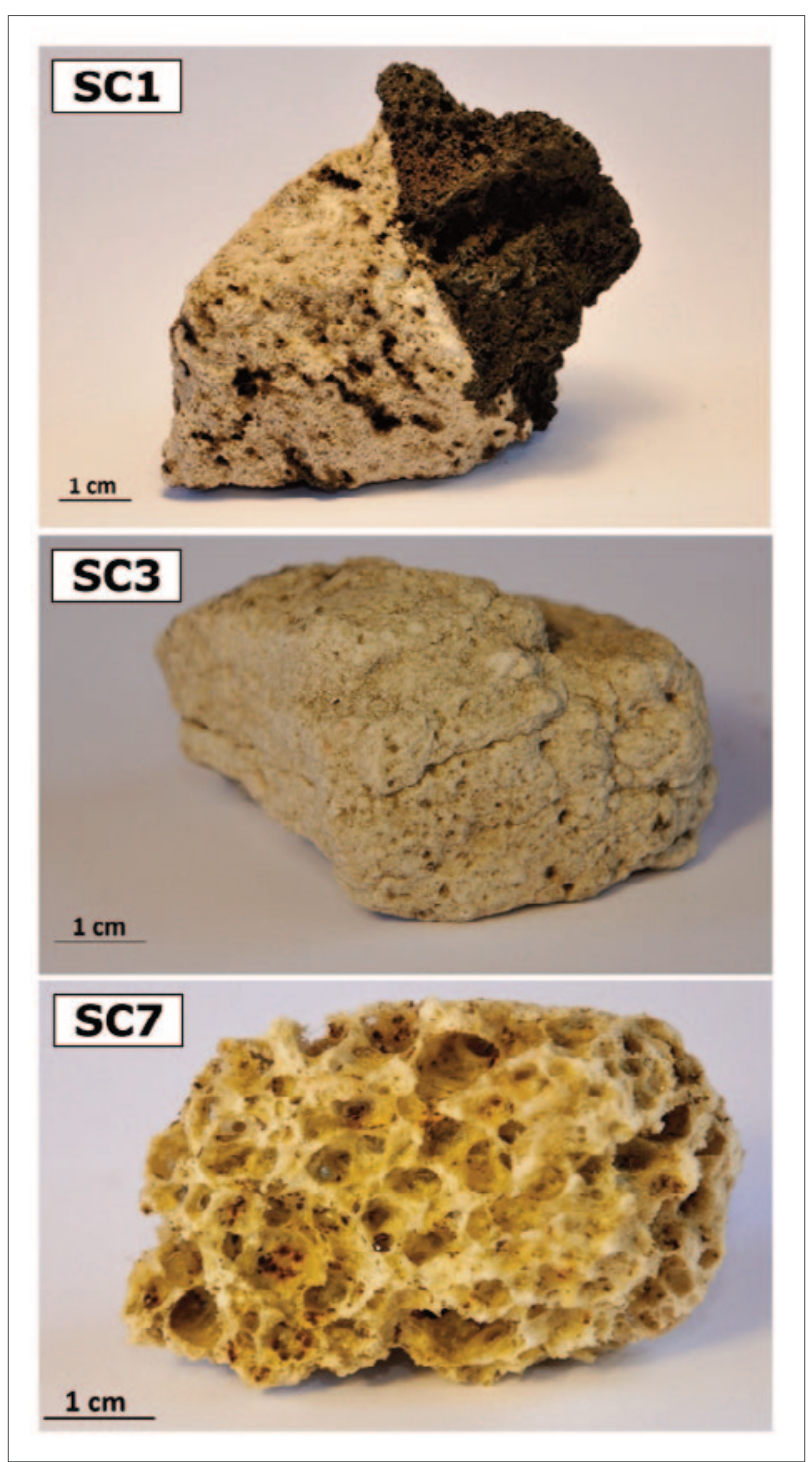

FIGURE 1. Samples at macroscopic scale. On the top, xenolith SC1 (brown portion) is associated with the hosting lava rock. Sample SC3 has a more compact structure, whereas SC7 shows high vesiculation, with vesicles up to $5 \mathrm{~mm}$ in size.

sedimentary rocks [Zambrano et al., 2017] and volcanic samples [Zandomeneghi et al., 2010; Baker et al., 2012a; Lanzafame et al., 2017]. Moreover, the 3D approach has been also demonstrated to be the best technique to unravel the complex spatial relations developed by vesicle/pore networks [Baker et al., 2012b; Zambrano et al., 2017].

\section{THE ETNEAN BASEMENT}

Mount Etna volcano rises to $3340 \mathrm{~m}$ a.s.l. above the eastern coast of Sicily (Figure 2a). Its activity can be tracked up to $500 \mathrm{ka}$ ago, when fissure-type eruptions took place in the submarine area east of the present ed- 

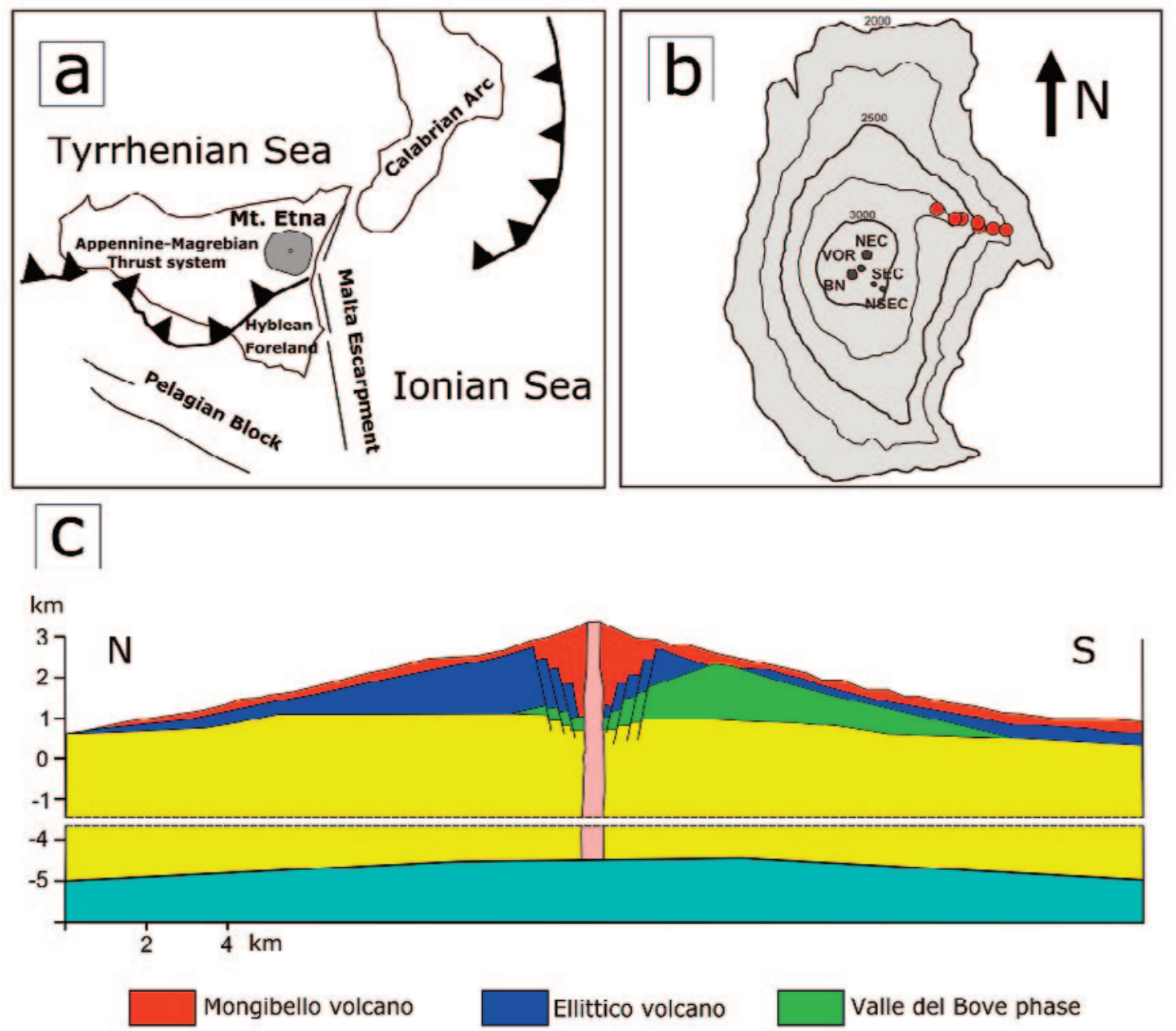

Appenninic-Maghrebian chain

Hyblean Plateau

FIGURE 2. a) Simplified regional geological map of Sicily showing Mount Etna location and main structural features; b) Map of Mount Etna summit craters Voragine (VOR), Bocca Nuova (BN), North East Crater (NEC), South East Crater (SEC) and New South East Crater (NSEC) and samples location on the NE sector of Mount Etna (red circles); c) Schematic N-S geological cross-section of Etna [modified after Branca et al., 2011 and Heap et al., 2013] showing the different volcanic edifices composing the stratovolcano and overlapping the Appenninic-Maghrebian Chain.

ifice, with emission of basic tholeiites [Corsaro and Pompilio, 2004]. This phase of the volcano activity continued with eruptions in sub-aerial environment until $220 \mathrm{ka}$ ago, when a transition towards alkaline$\mathrm{Na}$ products marked the onset of the Timpe phase, which built a first lava-shield edifice [Tanguy, 1997]. About 110 ka ago a new phase named Valle del Bove (Figure 2c) was responsible for the beginning of the central-type volcanism [De Beni et al., 2011] that continued in the last phase of the activity which started about $60 \mathrm{ka}$ ago with the building of the Ellittico edifice and later with the Mongibello volcano, developed on the remains of a caldera collapse occurred $15 \mathrm{ka}$ ago [Coltelli et al., 2000]. Mongibello is the presently active volcano, characterized by a persistent degassing from its summit craters [Figure 2b, Ferlito et al., 2014; Ferlito, 2018] and frequent effusive and explosive emissions of basalts which covered about $88 \%$ of the Etna surface in the last $15 \mathrm{ka}$ [Branca and Ferrara, 2013]. These volcanic products cover the sedimentary substratum that reaches, beneath the summit craters, an altitude of 1100 meters a.s.l. (Figure 2c) with a conical-shape geometry described by Ogniben [1966] and reappraised by Branca and Ferrara [2013].

Although efforts have been made to unravel the morphostructural features, the nature and characters of the sedimentary units beneath Mount Etna still remain poorly understood [see Branca and Ferrara, 2013 and 
references therein]. However, hints are provided by the complex geology of Eastern Sicily. The present volcano edifice most likely rests above the sedimentary formations forming the front of the collision belt (ApenninicMaghrebian Orogen) grown at the margin of the Pelagian Block of the Africa promontory [Burollet et al., 1978] during the Neogene-Quaternary Europe-Africa convergence [Dewey et al., 1989; Ben Avraham et al., 1990]. In this region, the two colliding continental margins have produced some crustal domains. Remnants of the crystalline nappes Hercynian in age at the southernmost edge of the Calabrian arc [Ogniben, 1960] represent the deformed European margin which has largely overthrusted the Maghrebian thrust belt [Lentini and Vezzani, 1978; Ben Avraham et al., 1990; Lentini et al., 1996]. The Maghrebian thrust belt is made up of superimposed tectonic units including Mesozoic sedimentary sequences detached from both continental and oceanic crusts and Cenozoic flyschtype cover [Finetti et al., 2005; Lentini et al., 2006]. In the Etna region, the Apenninic-Maghrebian Orogen (AMO) is represented by the Alpine Tethis sequences formed by the Sicilide Tecton unit. This unit is formed by clays and terrigenous succession such as the $\mathrm{Nu}$ midian, Troina-Tusa and Mt Soro flysches, outcropping in both NW and SW sector of Mount Etna [Branca et al., 2011].

Beneath these sequences are the Mesozoic to MidPleistocene carbonates of the Hyblean Plateau, given by succession of limestone and dolomite [Lentini, 1982; Grasso and Lentini, 1982; Pedley and Grasso, 1992; Heap et al., 2013]. These units should be located at a depth of about $5 \mathrm{~km}$ beneath the volcano [Figure 2c, Tibaldi and Groppelli, 2002; Andronico et al., 2005], with an average thickness of about $10 \mathrm{~km}$ [Yellin-Dror et al., 1997].

\section{SAMPLES AND ANALYTICAL METHODS}

Seven samples (labeled SC1-SC7) were collected on the northeastern side of Mount Etna, in the area between Serra delle Concazze (2200 m a.s.l.) and Pizzi Deneri (2847 $\mathrm{m}$ a.s.l.). Xenoliths were found within the pyroclasts (coarse scoriae and lapilli) erupted during the paroxysms that occurred from 2011 to 2016 [Viccaro et al., 2014; Ferlito et al., 2017; Pompilio et al., 2017].

Samples have centimetric size (up to $10 \mathrm{~cm}$ ) (Figure 1), although sometimes in the field one may find larger xenoliths of the same kind (up to $40 \mathrm{~cm}$ in diameter). With the exception of SC3 sample, these rocks are very friable, white to brown in color, and mostly made of quartz grains with size from $200 \mu \mathrm{m}$ to $1.2 \mathrm{~mm}$. Inclusion of oxides, zircon and sphene are found within the grains or at their contact. At macroscopic scale, samples are characterized by fractured portions filled by green to brown glass and containing vesicles in various amounts (Figure 1). Sample SC7 differs from the others, showing a foam-like structure characterized by the scarce presence of grains and a high number of large (up to $5 \mathrm{~mm}$ ) vesicles.

\subsection{X-RAY FLUORESCENCE (XRF) ANALYSES}

Whole rock major and trace element concentration on seven samples (Table 1) has been determined by XRay Fluorescence (XRF) analyses using a Philips PW2404 WD-XRF spectrometer standardized according to Germanique [1994]. The matrix effect was reduced using the method proposed by Franzini et al. [1972]. The precision is between 1 and $5 \%$ for major elements and between 5 and $10 \%$ for trace elements [Franzini et al., 1972]. The accuracy was monitored using international standards and was always better than $10 \%$. Water content was determined by gravimetric measurements as L.O.I. (Loss on Ignition) and successively corrected for iron oxidation.

\subsection{BACK-SCATTERED ELECTRON (BSE) IMAGING AND SEM ANALYSIS}

Textural investigations on high-contrast back-scattered electron (BSE) images and chemical analyses for crystals and glass have been made at the Dipartimento di Scienze Biologiche, Geologiche e Ambientali, University of Catania (Italy) with a Tescan Vega-LMU scanning electron microscope (SEM) equipped with an EDAX Neptune XM4-60 microanalyzer operating by an energy dispersive system characterized by an ultra-thin Be window coupled with an EDAX WDS LEXS (wavelength dispersive low energy X-ray spectrometer) calibrated for light elements. Operating conditions were set at $20 \mathrm{kV}$ accelerating voltage and ca $8 \mathrm{nA}$ beam current for obtaining high resolution BSE images and $20 \mathrm{kV}$ accelerating voltage and $0.2 \mathrm{nA}$ beam current for analyzing major element abundances. Chemical spot analysis on intergranular vesicle-rich glass were performed on selected samples (SC3, SC5 and SC7). SC4 grains and glass were investigated by 3 compositional profiles made by 14 spot analysis. 


\begin{tabular}{|c|c|c|c|c|c|c|c|}
\hline Sample & SC1 & $\mathrm{SC} 2$ & SC3 & $\mathrm{SC} 4$ & SC5 & SC6 & SC7 \\
\hline $\mathrm{SiO}_{2}$ & 83.58 & 88.62 & 97 & 93.45 & 82.7 & 82.53 & 59.45 \\
\hline $\mathrm{TiO}_{2}$ & 0.83 & 0.55 & 0.18 & 0.49 & 0.68 & 0.73 & 0.55 \\
\hline $\mathrm{Al}_{2} \mathrm{O}_{3}$ & 6.22 & 3.89 & 1.01 & 2.24 & 5.79 & 5.62 & 19.96 \\
\hline $\mathrm{Fe}_{2} \mathrm{O}_{3}$ & 1.99 & 1.93 & 0.42 & 0.82 & 3.13 & 3.33 & 3.32 \\
\hline $\mathrm{MnO}$ & 0.04 & 0.05 & 0.01 & 0.03 & 0.07 & 0.06 & 0.04 \\
\hline $\mathrm{MgO}$ & 0.56 & 0.51 & 0.02 & 0.2 & 0.83 & 0.88 & 0.07 \\
\hline $\mathrm{CaO}$ & 2.16 & 1.55 & 0.2 & 0.96 & 2.65 & 2.63 & 1.59 \\
\hline $\mathrm{Na}_{2} \mathrm{O}$ & 1.74 & 1.21 & 0.48 & 0.77 & 1.65 & 1.74 & 6.49 \\
\hline $\mathrm{K}_{2} \mathrm{O}$ & 2.43 & 1.23 & 0.48 & 0.75 & 2.01 & 1.92 & 7.19 \\
\hline $\mathrm{P}_{2} \mathrm{O}_{5}$ & 0.12 & 0.11 & 0.01 & 0.05 & 0.13 & 0.19 & 0.08 \\
\hline L.0.1. & 0.32 & 0.36 & 0.2 & 0.25 & 0.36 & 0.35 & 1.26 \\
\hline $\mathrm{Sr}$ & 268 & 171 & 18 & 73 & 275 & 298 & 105 \\
\hline V & 65 & 42 & 7 & 22 & 70 & 77 & 23 \\
\hline $\mathrm{Cr}$ & 26 & 15 & 13 & 17 & 15 & 13 & 6 \\
\hline Co & 3 & 3 & 1 & 2 & 6 & 6 & 2 \\
\hline $\mathrm{Ni}$ & 11 & 4 & 4 & 7 & 11 & 9 & 6 \\
\hline $\mathrm{Zn}$ & 31 & 30 & 9 & 17 & 42 & 36 & 39 \\
\hline $\mathrm{Rb}$ & 41 & 24 & 11 & 14 & 39 & 38 & 65 \\
\hline$Y$ & 18 & 11 & 3 & 10 & 17 & 13 & 9 \\
\hline $\mathrm{Zr}$ & 501 & 360 & 187 & 638 & 329 & 305 & 101 \\
\hline $\mathrm{Nb}$ & 17 & 10 & 2 & 8 & 16 & 18 & 29 \\
\hline $\mathrm{Ba}$ & 670 & 127 & 25 & 248 & 191 & 228 & 244 \\
\hline $\mathrm{La}$ & 30 & 25 & 11 & 17 & 26 & 36 & 54 \\
\hline $\mathrm{Ce}$ & 42 & 33 & 5 & 27 & 55 & 44 & 73 \\
\hline $\mathrm{Pb}$ & 7 & 9 & 5 & 8 & 9 & 6 & 13 \\
\hline Th & 6 & 3 & 1 & 4 & 4 & 4 & 7 \\
\hline
\end{tabular}

TABLE 1. Results of whole rock analyses for major (wt.\%) and trace (ppm) elements.

\subsection{SYNCHROTRON X-RAY MICROTOMOGRAPHY [SRuCT] MEASUREMENTS}

The study was conducted on portions of xenoliths with lateral size of 5-6 mm. Three-dimensional imaging was performed by high-resolution SR $\mu \mathrm{CT}$ in phase-contrast mode [Cloetens et al. 1997; Polacci et al., 2010; Baker et al., 2012a] at the SYRMEP beamline of the Elettra-Sincrotrone Trieste laboratory in Basovizza (Trieste, Italy), employing either monochromatic or polychromatic X-ray beam delivered by a bending magnet source illuminating the sample in transmission geometry. The monochromatic beam using a double crystal monocromator Si 111, was adopted for the SC6 and SC7 samples, characterized by large-sized vesicles, whereas polychromatic beam at higher resolution was employed for investigating the SC1-SC5 samples.

With the monochromatic beam configuration, the sample-to-detector distance was set at $150 \mathrm{~mm}$, X-ray energy at $25 \mathrm{keV}$ and 1800 radiographic projections were collected with an exposure time of 1.5 seconds. Projections were acquired by a 12-bit, 4008 x 2672 pixels CCD camera (VHR, Photonic Science) with an effective pixel size of $4.5 \mu \mathrm{m}$. Applying a 2x2 binning on chip, an output isotropic voxel size of $9 \mu \mathrm{m}$ was obtained for image acquisition.

Regarding the white beam configuration, filters (1.5 $\mathrm{mm} \mathrm{Si}+1 \mathrm{~mm} \mathrm{Al}$ ) were used to suppress the contribution of low energies in the beam spectrum. The sample-to-detector distance was set at $100 \mathrm{~mm}$. For each sample, 1800 projections were recorded with an exposure time/projection of $1 \mathrm{~s}$. Two sets of measurements were carried out with an effective pixel size of the detector set at 1.37 and $2.62 \mu \mathrm{m}$, yielding a maximum field of view of about 2.8 $\times 2.8$ and $5.4 \times 5.4 \mathrm{~mm} 2$, respectively. The detector used was an air-cooled, 16 bit, SCMOS camera (Hamamatsu C11440-22C) with a $2048 \times 2048$ pixel chip coupled with a high numerical aperture optic. These experiments were performed in "local area mode" [Lak et al., 2008; Maire and Withers, 2014], being the lateral size of samples larger than the horizontal field of view of the detector.

Reconstruction of the 3D tomographic slices was done with the Syrmep Tomo Project (STP) house soft- 
ware suite [Brun et al., 2017]. Different combinations of filters available in the STP software were applied to the datasets for reducing ring artefacts caused by detector inhomogeneity [Brun et al., 2013]. Owing to phasecontrast, the projection images display a mix of absorption-based contrast and edge effects. With the aim of improving the reliability of the segmentation process and morphological analysis, and to fully exploit the potential of phase-contrast SR $\mu \mathrm{CT}$, it is necessary to compute an image predominated by the real part of the complex refractive index $n=1-\delta+i \beta$ [eq. 1], where the real $(\delta)$ and imaginary $(\beta)$ parts are related to phase and absorption distribution of the sample, respectively.. This can be done by retrieving the phase distribution within the sample volume. We used the Transport of Intensity Equation (TIE) based algorithm [Paganin et al., 2002] implemented in the STP software. Phase-retrieval in combination with the Filtered Back-Projection algorithm [Herman, 1980] allowed us to obtain the 3D distribution of the complex refractive index $\mathrm{n}$ of the considered rocks. In principle, this class of algorithms can only be applied for homogeneous objects, characterized by a constant ratio $\gamma=\delta / \beta$. Although the considered samples do not satisfy this assumption, it has been demonstrated by Arzilli et al. [2015] that this kind of algorithm can still be employed, with some caution, even on multiphase volcanic rock samples. We used a priori known information about the samples, characterized by a constant $\gamma$. For the SC1-SC5 samples we adopted $\gamma=100$, for SC6-7 $\gamma=50$. These values allowed to enhance the contrast between vesicles, crystals/grains and glass of the samples.

\subsection{D IMAGE PROCESSING AND ANALYSIS}

The analysis of the 3D sample images allowed the quantification of the grain, glass and vesicle amount and their connectivity among the samples. Quantitative analyses were performed by means of Pore3D software library [Brun et al., 2010; http://www.elettra.eu/pore3d/]. From each of the original image stack we cropped out a Volume Of Interest (VOI) with variable sizes (Table 2). For SC1-SC5 we chose to perform experiments at two different scales (1.37 and $2.6 \mu \mathrm{m} /$ pixel) because of the inhomogeneous texture of some samples, in some cases presenting only localized vesiculation. In order to represent the SC6 and SC7 xenoliths, we performed only measurements at $9 \mu \mathrm{m} /$ pixel which resulted in a field of view large enough to catch their texture variability. In this regard we tested the representativeness of each VOI and defined the Representative Elementary Volumes (REVs) [Gitman et al.

\begin{tabular}{ccccc} 
Sample & $\begin{array}{c}\text { Voxel size } \\
\text { (um) }\end{array}$ & VOI $\left(\mathrm{mm}^{3}\right)$ & Density & $\begin{array}{c}\text { Connectivity } \\
\text { Density }\left(\mathrm{mm}^{-3}\right)\end{array}$ \\
SC1 & 2.6 & 18.9 & 0.7 & 983 \\
SC2 & 2.6 & 18.9 & 0.8 & 515 \\
SC3 & 2.6 & 18.9 & 0.05 & 125 \\
SC4 & 2.6 & 11.9 & 0.3 & 509 \\
SC5 & 2.6 & 18.9 & 0.6 & 604 \\
SC6 & 9 & 75.6 & 0.7 & 164 \\
& & & & \\
SC7 & 9 & 73.5 & 0.9 & 90 \\
\hline
\end{tabular}

TABLE 2. Results of 3D basic analysis on vesicles.

2007; Zandomeneghi et al., 2010] by the box-counting method [Al-Raoush and Papadopoulos, 2010]. This method consists of the iterative analysis of a variable (in our case the vesicle content expressed in vol.\%) in an increasing sub-volume extracted from the VOI. According to Costanza-Robinson et al. [2011] REV is defined as the minimum window length scale $(\mathrm{L})$ at which the variation of a measured system variable reaches a reasonable plateau. Measurements made at this scale are scale-independent and accurately represent a largest system. Results of REV estimations for our xenoliths in Figure 3 indicate that for pixel size $=2.6 \mu \mathrm{m}$ VOIs reach REV characteristics for $\mathrm{L}$ $>700$ pixels corresponding to a cubic VOI with lateral size of $1.8 \mathrm{~mm}$, whereas REV is not reached by volumes obtained at $1.37 \mathrm{um}$. Images of SC6 and SC7 collected in monochromatic mode at pixel size of $9 \mu \mathrm{m}$ reach REV characteristics for $\mathrm{L}>350$ (cubic VOI with lateral size of $3.15 \mathrm{~mm}$ ). On the basis of REV results, 3D analyses were performed on VOIs with size larger than L. In addition, the iterative procedure for individuating REV, if successful, testify the reliability of the measurements, since a large number of VOIs is investigated during this test.

The procedure for the image analysis using the Pore3D library consisted in the following steps:

- Filtering using the bilateral filter [Tomasi and Manduchi, 1998] in order to remove noise and preserve edges.

- Segmentation of the vesicle population by the Multi Otzu algorithm [0tsu, 1979], setting 3 classes of ob- 


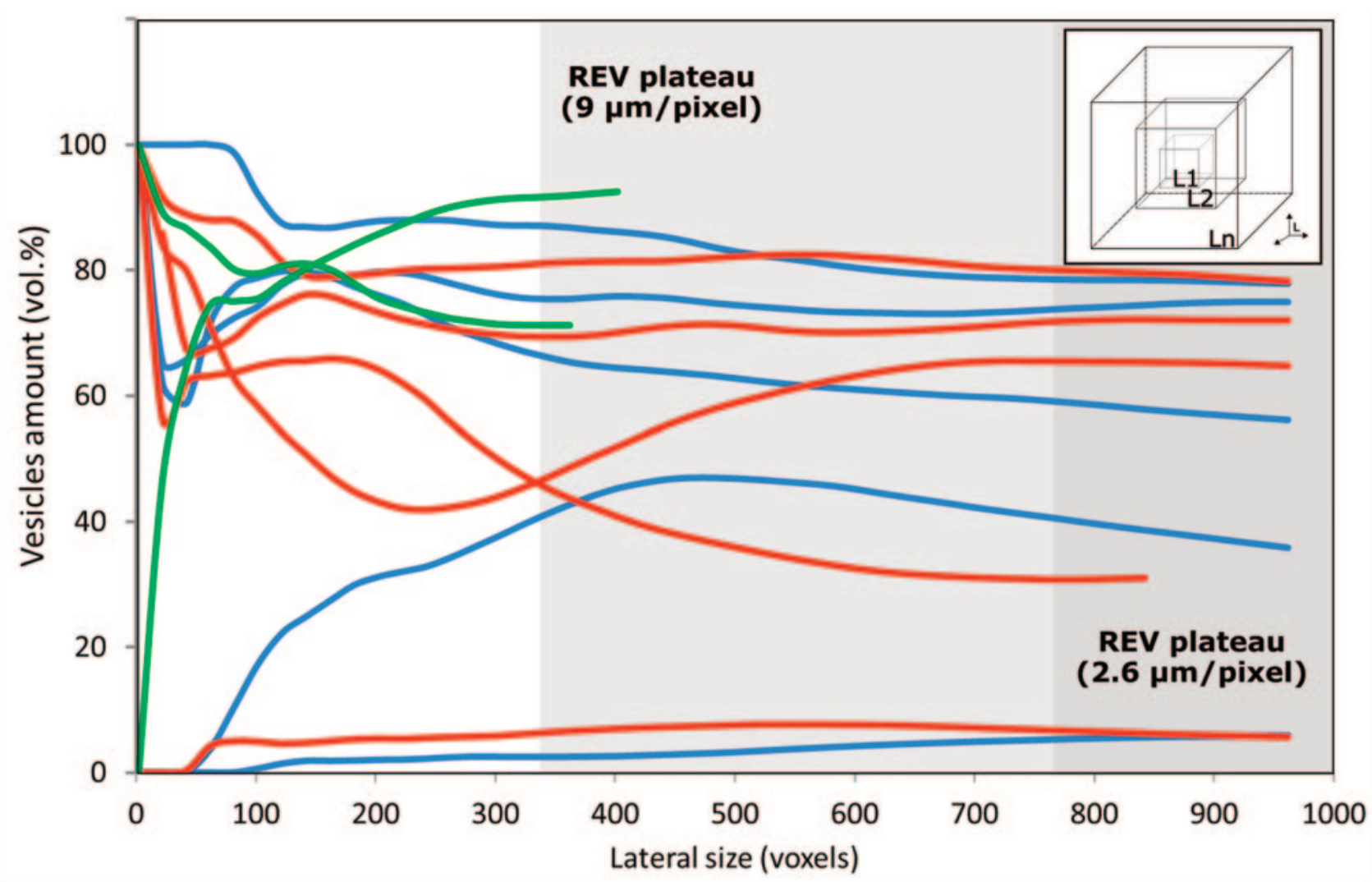

FIGURE 3. Result of the REV estimations by box counting method. Red and blue lines represent samples imaged at pixel size of 2.6 and $1.37 \mu \mathrm{m}$, respectively. In green samples SC6 and SC7 (pixel size $=9 \mu \mathrm{m}$ ). Grey fields indicate the minimum L value for REV characteristics. REV for volumes collected at $1.37 \mu \mathrm{m} /$ pixel is not reached by all samples at lateral size $<1000$ voxels. In the box is schematized the box counting method, which involves VOIs with increasing size (L1...Ln).

ject (vesicles, crystals and groundmass/glass). Where necessary, thresholds between two classes were manually adjusted after visual inspection.

- Evaluation of the density, the ratio between the total volume of the investigated objects (in our case crystals or vesicles) and the volume of the VOI.

The estimation of the quartz grain and glass amount was performed on VOIs with a pixel size of 2.6 and 9 $\mu \mathrm{m} /$ pixel, filtering the images by the 3D Median filter of the Fiji software. Images were manually segmented in order to extract the grain + glass phase (Figure 4) and then processed by erosion/dilation cycles [Brun et al., 2010] in order to erase the voxels corresponding to vesicle walls without affecting the original volume of quartz grains. By this process quartz grains were isolated and glass amount calculated subtracting the grain + vesicle phases from the total volume.

The connectivity of the vesicles was investigated and parametrized by the skeletonization of the segmented vesicles network using the GVF Skeletonization algorithm [Brun and Dreossi, 2010]. This procedure allowed us to elaborate the "spine" of a 3D object and then to analyze its morphology. Skeletonization was applied on reduced VOIs from the datasets acquired at pixel size of 2.6 $\mu \mathrm{m} /$ pixel $(768 \times 768 \times 768$ voxels corresponding to $\sim 8$ $\mathrm{mm}^{3}$ ) and on the original VOIs from the dataset collected at $9 \mu \mathrm{m} /$ pixels. The choice of working only on sub-volumes of the VOIs was made because of computation capacity limits and on the basis of REVs results. The parameter used to evaluate the degree of interconnection of the vesicle is the connectivity density [see Lanzafame et al., 2017; Zambrano et al. 2017], a value derived from the skeleton of the connected pore network and representing the number of redundant connections normalized to the total investigated volume. It is computed as $\mathrm{CD}=$ $[1-(n-b)] / V$ [eq. 2] being $n$ the number of bubbles, $b$ the number of bubble-to-bubble branches of the skeleton and V the investigated volume [Brun et al., 2010]. Positive results of $\mathrm{CD}$ indicate highly connected networks, whereas negative values are typical of scarce connection of the analyzed objects.

Volume visualization of the image stacks of the samples was performed by volume rendering procedures using the commercial software Avizo 8.1. 


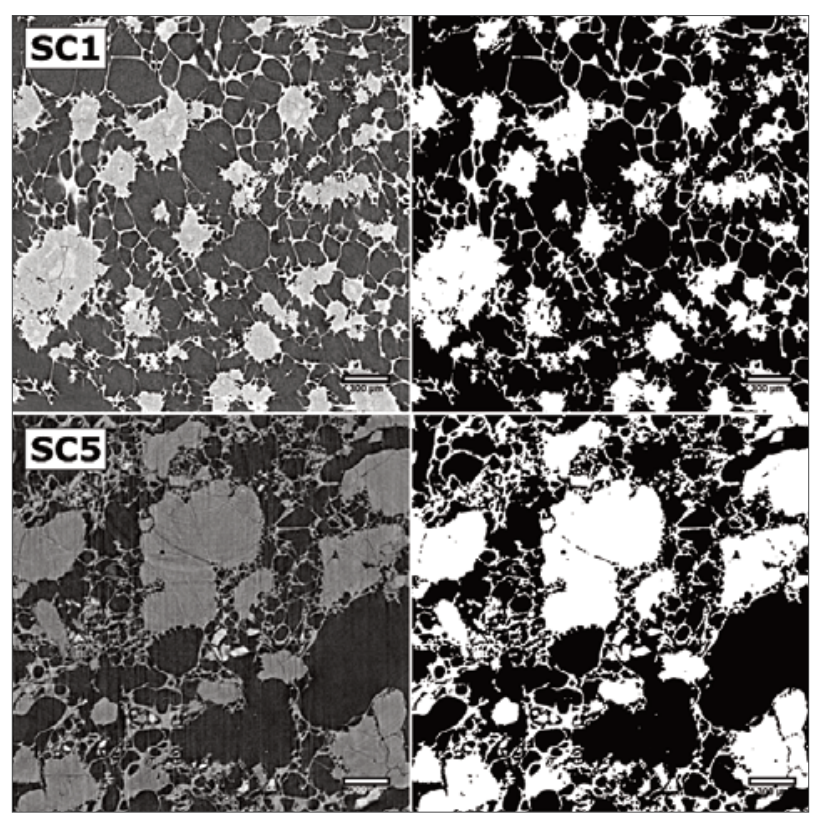

FIGURE 4. Example of the segmentation protocol applied to two samples. On the left the original images, on the right the binary images obtained by manual segmentation of the vesicle phase.

\begin{tabular}{ccccc} 
& Quartz & Vesicles & Glass & Partial melting (\%) \\
\hline SC1 & 12.7 & 72.2 & 15.2 & 54.5 \\
SC2 & 11.3 & 77.7 & 11.0 & 49.3 \\
SC3 & 63.9 & 5.4 & 30.7 & 32.4 \\
SC4 & 54.1 & 31.0 & 14.8 & 21.5 \\
SC5 & 17.3 & 64.2 & 18.5 & 51.6 \\
SC6 & 19.7 & 72.0 & 8.3 & 29.6 \\
SC7 & $<0.1$ & 92.0 & 7.9 & $>99$ \\
\hline
\end{tabular}

TABLE 3. Volume fractions (in \%) of the samples components and calculated degree of parental rock partial melting.
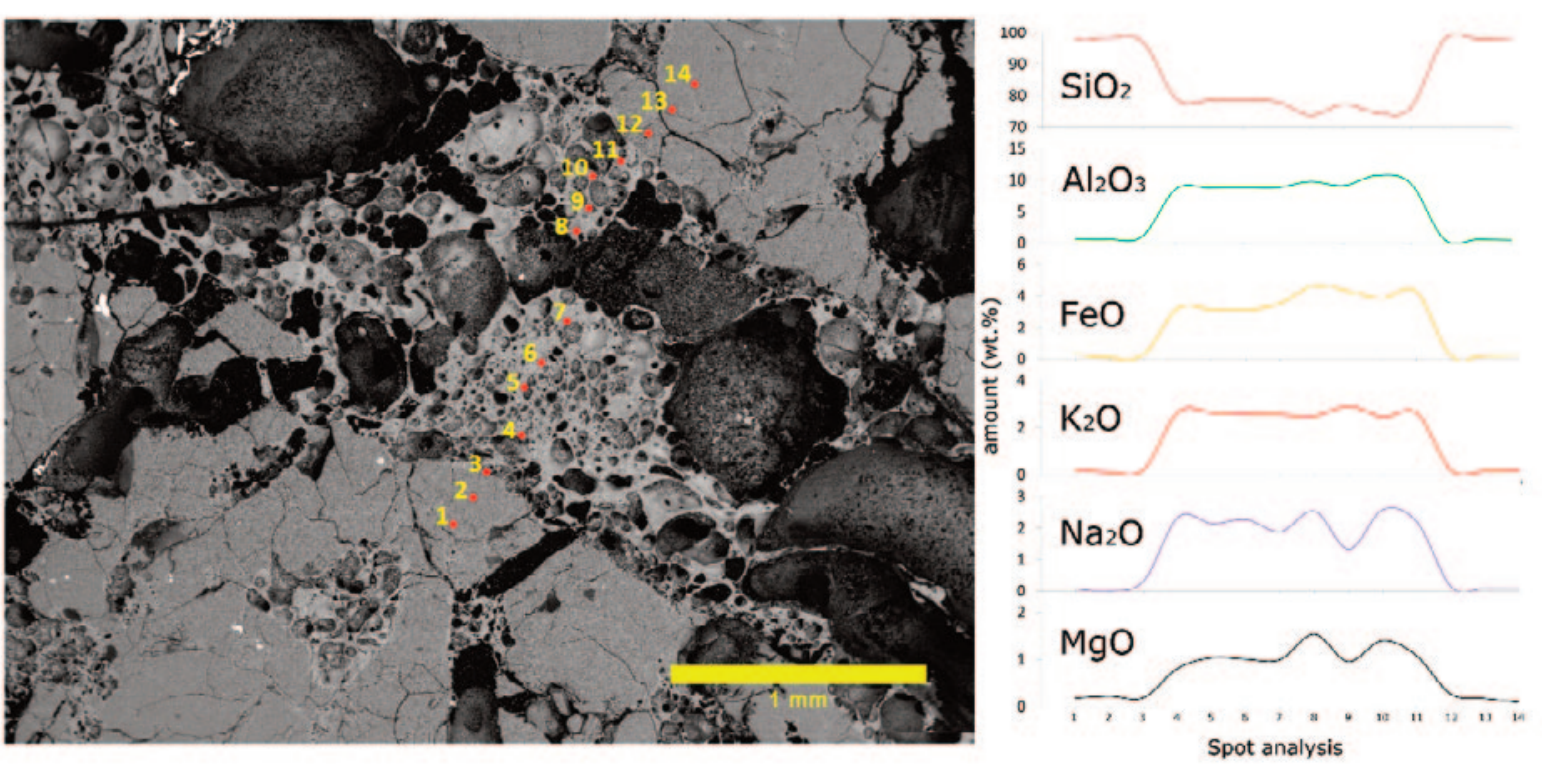

FIGURE 5. Compositional profile of the contact zone between quartz grains and vesiculated melt of SC4 sample.

\section{RESULTS}

\subsection{CHEMICAL COMPOSITION, 2D AND 3D TEXTURAL FEATURES}

Results of the whole rock composition by X-Ray Fluorescence (Table 1) suggest a quartzarenitic nature of the SC1 to SC6 parental rocks, mainly constituted by $\mathrm{SiO}_{2}$ (> 82 wt.\%) with $\mathrm{Al}_{2} \mathrm{O}_{3}<6.3$ wt.\% and Alkali $\left(\mathrm{Na}_{2} \mathrm{O}+\mathrm{K}_{2} \mathrm{O}\right)<4.2$ wt.\%. Glass compositions investigated by SEM spot analysis and traverses (Table $\mathrm{S}$ and
Figure 5) have wide composition and in general reveal a decrease in $\mathrm{SiO}_{2}(64<\mathrm{SiO} 2$ wt.\% < 88) and an increase in $\mathrm{Al}_{2} \mathrm{O}_{3}$ and Alkali content with respect to the whole rocks. Mass balances of the glass + quartz grains composition Vs. whole rock (Table S2) evidence a good correlation between the calculated and the whole rock $\mathrm{SiO}_{2}$ content; whereas for some elements (e.g. $\mathrm{Al}, \mathrm{Ca}, \mathrm{K}$, $\mathrm{Na}$ ) the calculated compositions result enriched or depleted with respect the whole rock. This discrepancy could be ascribed to the heterogeneity of the glass com- 
position, which originates from the partial melting of the quartz crystals and total melting of the accessory minerals. The SC7 sample has a foam-like appearance with rare quartz grains and vesicles up to millimetric size separated by thin vitrified walls. Whole rock analysis indicates an $\mathrm{SiO}_{2}$ content of 60.2 wt.\%, $\mathrm{Al} 203=20.21$ wt. \% and total Alkali content = 13.85 wt.\%.

Textural observations on 2D images collected on thin sections and on 3D images from SR- $\mu \mathrm{CT}$ revealed that the SC1-SC6 samples are made by two principal phases: rounded quartz grains and glassy matrix with variable amount of vesicles (Table 3). Three-dimensional images collected at $1.37 \mu \mathrm{m} / \mathrm{pixel}$ allowed us to investigate the quartz grains morphology, which evidenced that these components are always rounded with jagged borders (Figures 4 and 6 - left column). Images collected at $2.6 \mu \mathrm{m} / \mathrm{pixel}$ and $9 \mu \mathrm{m} / \mathrm{pixel}$ were used to investigate the geometry of the glassy matrix separating the quartz grains and containing vesicles of micrometric to millimetric size, divided by tiny walls (Figures 4 and 6). Results of the vesicle amount calculated on 3D images are comparable for both sets acquired at 1.37 and $2.6 \mu \mathrm{m} /$ pixel (SC51-SC5 samples). Vesicularity of the SC6 and SC7 samples was evaluated on images acquired at $9 \mu \mathrm{m} /$ pixel.

On textural basis, samples can be divided in:

a) Highly vesiculated xenoliths, including the SC1, SC2, SC5 and SC6 samples characterized by articulated and extensive networks of vesicles resulting in a foam-like appearance. These xenoliths show a vesicle content up to 77 vol.\% of the total volume, in which are dispersed isolated grains of quartz with lateral size up to $1.2 \mathrm{~mm}$. The glass fraction constituting the vesicle walls represent the 8-20 vol.\% of the rock, indicating a $29-55$ vol. $\%$ of partial melting.

b) Fractured SC4 xenolith, with texture made by grains with size up to $1.2 \mathrm{~mm}$ and a massive presence of large fractures often filled by vesiculated glass. Quartz grains of this sample occupy the $55 \%$ of the total volume, whereas glass is less than 15 vol.\%. The estimated partial melted volume of the parental rock does not exceed 22 vol.\%.

c) Poorly vesiculated SC3 xenolith, exhibiting a compact structure formed by quartz grains (60 vol.\%) with a maximum size of $700 \mu \mathrm{m}$ surrounded by thin veins of glass. This sample is characterized by low and localized presence of vesicles (5.5 vol.\%) enclosed in the glass phase (30 vol.\%). Vesicles are often spherical and appear associated along fractures bordering the quartz grains.

d) Foamy SC7 sample, which differs from the other samples being almost entirely made by glass with rare grains of quartz and very large vesicles (Figure 7). This rock most probably underwent a total melting, conserved its foam-like structure, and was not totally assimilated by the hosting-magma.

In volumes obtained at $2.6 \mu \mathrm{m} / \mathrm{pixel}$ (SC1-5), vesicles form networks with a moderate to high degree of connections as demonstrated by the positive $C D$ values (Table 2). Samples from group (a) show the highest CD value, due to their extended vesicle network, whereas sample SC3 shows the lowest value because of its compact structure and the small amount of vesicles. Positive $\mathrm{CD}$ values are also shown by volumes obtained at 9 $\mu \mathrm{m} /$ pixel (SC6-7) indicating also for these xenoliths a marked coalescence of vesicles.

\section{DISCUSSION}

This discussion will focus on: the origin of the xenoliths sampled in this work and on the explanation of their textural features, and in particular the highly vesiculated interstitial glass within the quartz grains. Lastly, we formulate a model for their origin and history, taking also in account the marked textural and chemical differences between SC1-SC6 and SC7 samples.

The $\mathrm{SiO}_{2}$ contents of SC1-SC6 (85 to $95 \mathrm{wt} . \%$ ) is used as the starting point for discussing their origin and texture. In fact, these high values coupled with textures given mainly by quartz grain dispersed in a extensively vesiculated glass indicate, as very likely, an origin from the sedimentary basement that lays beneath the volcanic cover. The sedimentary succession outcropping in the Mount Etna area includes several formation and rock types, from the limestone of the Hyblean Plateau to the terrigenous Sicilian formations [Dongarra and Ferla, 1982; Grasso and Lentini, 1982; D’Errico et al., 2014]. However, the topmost sedimentary layers, cropping out just to the west of the volcanic edifice, are the alternate clays and quartzarenitic sandstones of the Numidian Flysch [Wezel, 1969; Thomas, 2011; Barbera et al., 2014; Pinter et al., 2016 and references therein]. It seems plausible that the quartzarenitic xenoliths found embedded in many Etnean lavas, and among the scoriae and pyroclastic material emitted during the Strombolian and lava fountain activity, rightly comes from this sed- 


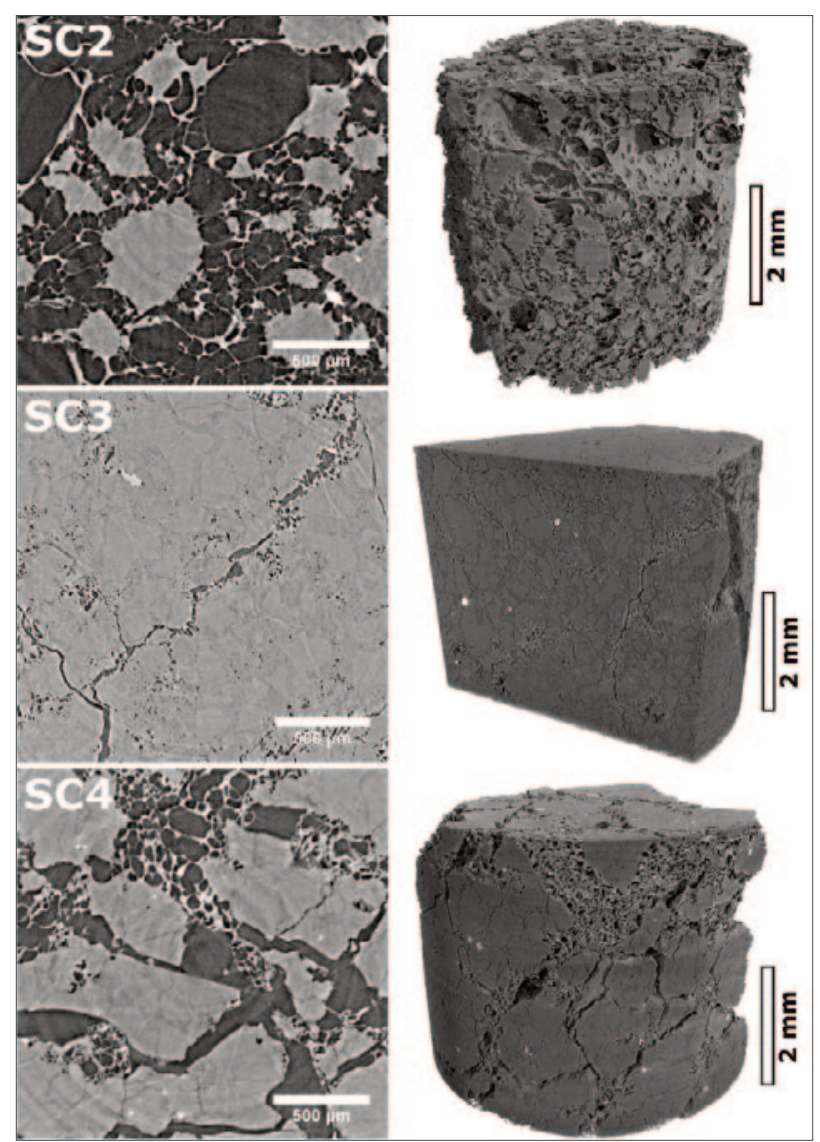

FIGURE 6. Reconstructed slices ( $1.37 \mu \mathrm{m} /$ pixel) and volume renderings $(2.6 \mu \mathrm{m} / \mathrm{pixel})$ of selected representative samples. SC2 and SC4 show the massive presence of interstitial vesiculated glass, whereas SC3 is poorly affected by vesiculation. In this sample, glass forms a continuous phase (dark grey) that separates quartz grains (light grey).

imentary formation, as already hypothesized by Michaud [1995]. To prove this point, we have compared the petrographic and petrochemical features of the xenoliths with those of mudrocks and sandstones of the $\mathrm{Nu}-$ midian Flysch described in detail by Barbera et al. [2009, 2014]. Sandstones of the Numidian flysch are characterized by a high amount of modal quartz (> 95\% vol.\%) and low percentages of feldspar and lithic fragments. Mudrocks are characterized by non-clay fraction (quartz $=5-44$ vol.\%, feldspars 3-14 vol.\% and low contents of Fe Oxides) and clay minerals (kaolinite and smectite in the order of 50 vol.\%, illite and chlorite as subordinate phases). In Figure 8 are reported the xenoliths composition expressed as $\mathrm{SiO}_{2}$ wt.\% Vs. major oxides. Diagrams indicate that the SC2, SC3 and SC4 samples fall within or close to the compositional field of the sandstone member of the Numidian Flysch [Barbera et al., 2009; 2014]. Samples SC1, SC5 and SC6 are slightly less siliceous and fall in an intermediate field. Three dimensional investigations, coupled with SEM spot analysis, revealed that textures consist of quartz grains separated by a glass phase. These results offer strong hints to hypothesize that the origin of the SC1SC6 samples could be attributed to the quartzarenitic portion of the Numidian Flysch laying beneath the volcano edifice. On the contrary, the chemical signature of the SC7 sample indicate its origin from the mudrock portion of the Numidian Flysch (Figure 8).

The interstitial glass filling the space between quartz grains in SC7 shows trachytic to rhyolitic composition (SiO2 > 64 wt.\% and Alkali = 7-14 wt.\%) whereas SC1SC6 glass is rhyolitic $\left(\mathrm{SiO}_{2}>70 \mathrm{wt} . \%\right.$ and Alkali $=4-$ $12 \mathrm{wt} . \%$ ) and lays in a field between the mudrocks and the quartzarenites (Figure 8). Similar compositions have been reported by Mollo et al. [2017] for glass in an Etnean xenolith associated to products emitted during the March 2013 paroxysmal sequence and by Michaud [1995] for siliceous xenoliths found in historic lavas of Mount Etna. The genesis of this glass can be related to the partial melting of the quartzarenites captured by magma rising through the plumbing system of Mount Etna. The analysis of microtomographic images allowed us to calculate the amount of glass in the samples and thus to estimate the degree of partial melting, which affected $\sim 21$ to $\sim 55$ vol.\% of the parental rocks. This veritable process could have been improved, or even driven, not only by the high temperature that flysch underwent when in contact with magma $\left[\sim 1150{ }^{\circ} \mathrm{C}\right.$, cfr. Mollo et al., 2011] but especially by the flux of magmatic gasses, that are much more efficient in carrying the heat and induce partial melting [Ferlito et al., 2017; Ferlito, 2018]. In this regard, evidence of high gas content in the xenoliths is the large number and size of vesicles within the glass phase.

The origin of this gas is an interesting point to be discussed, since quartzarenitic sandstones of Numidian Flysch are mostly made of quartz (> 95 vol.\%), with scarce presence of single grains of feldspar (plagioclases $+\mathrm{k}$-feldspar $<5$ vol.\%) and accessory rock fragments given by fine-grained $(<0.06 \mathrm{~mm})$ carbonates, sedimentary clasts, micas and/or chlorites. Among these minerals, only micas could contain water in their lattice, but their scarce amount in the sandstones (generally less than 1 vol.\%) does not justify the high number and volume of coalescent vesicles shown by the xenoliths. One plausible hypothesis to explain such a high amount of vesicles is that the gas phase inflating the interstitial melt comes from volcanic gases (mostly $\mathrm{H}_{2} \mathrm{O}$ and $\mathrm{CO}_{2}$ ) fluxing the magmas of the Etnean feeding system [Fer- 


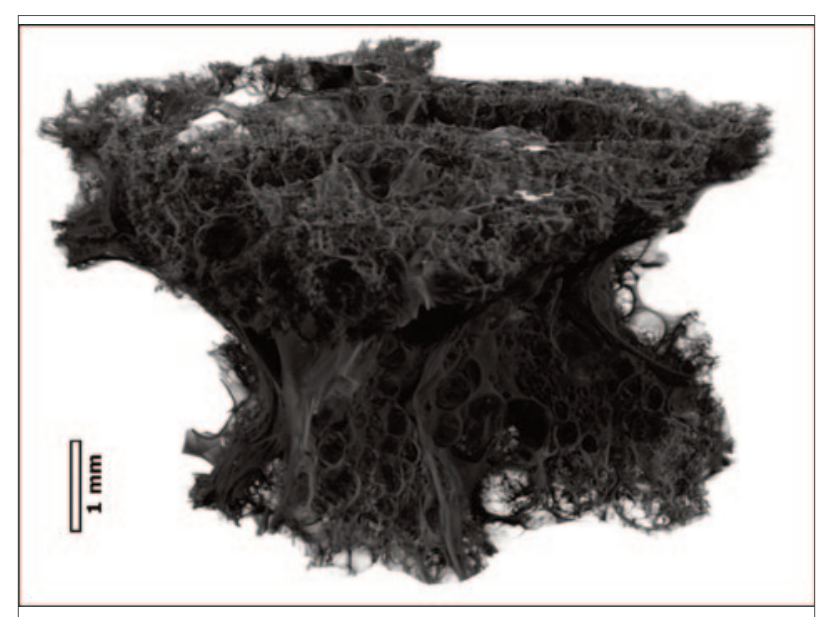

FIGURE 7. Volume renderings ( $9 \mu \mathrm{m} /$ pixel) of the foam-like SC7 sample, given by highly vesiculated glass with rare crystals (bright objects on the top).

lito et al., 2014, 2017; Ferlito, 2018] and therefore the embedded xenoliths. To prove this, we have modeled the amount of water that can be dissolved in the anhydrous melt generated by the partial melting of the xenoliths. The sediments of the Maghrebian-Appenine Chain basement, source of the xenoliths parental rocks, extend from 1100 meters a.s.l. to $~ 4000 \mathrm{~m}$ b.s.l [Tibaldi and Groppelli, 2002 and reference therein] and are covered by 2240 m of volcanic products. Considering a rock den- sity of $\sim 2750 \mathrm{~kg} / \mathrm{m}^{3}$ for the volcanites and $\sim 2650$ $\mathrm{kg} / \mathrm{m}^{3}$ for the sedimentary basement, the lithostatic pressure at these depths ranges between 60 (top of the sedimentary basement - $1100 \mathrm{~m}$ a.s.l.) and $190 \mathrm{MPa}$ (4 km b.s.l.). The water solubility in the interstitial melt was modeled by VolatileCalc 2.0 macro for Excel [Newman and Lowenstern, 2002] considering a liquid with rhyolitic composition such that generated by the sandstone partial melting and a temperature of $1150{ }^{\circ} \mathrm{C}$, typical for Etnean trachybasalts [Mollo et al., 2011]. Results indicate that for the above mentioned conditions a water amount comprised between 2.3 and 5 wt.\% can be stored in the melt formed within the sandstone rocks. Once xenoliths reach the shallower portion of the plumbing system $(\mathrm{P}<60 \mathrm{MPa}$, depth $<2240$ meters beneath summit craters), immediately before the eruption, such an amount of water starts exsolving, forming vesicles and giving origin to the characteristic foam-like appearance of the samples.

Alongside the hydration of the newly produced melt by partial melting of the parental rock, gas fluxing could play a major role in the partial melting itself. Recently it has been demonstrated by Ferlito et al. [2017] that high gas fluxes coming from depth and migrating independently from magma are able to trigger the partial melt-

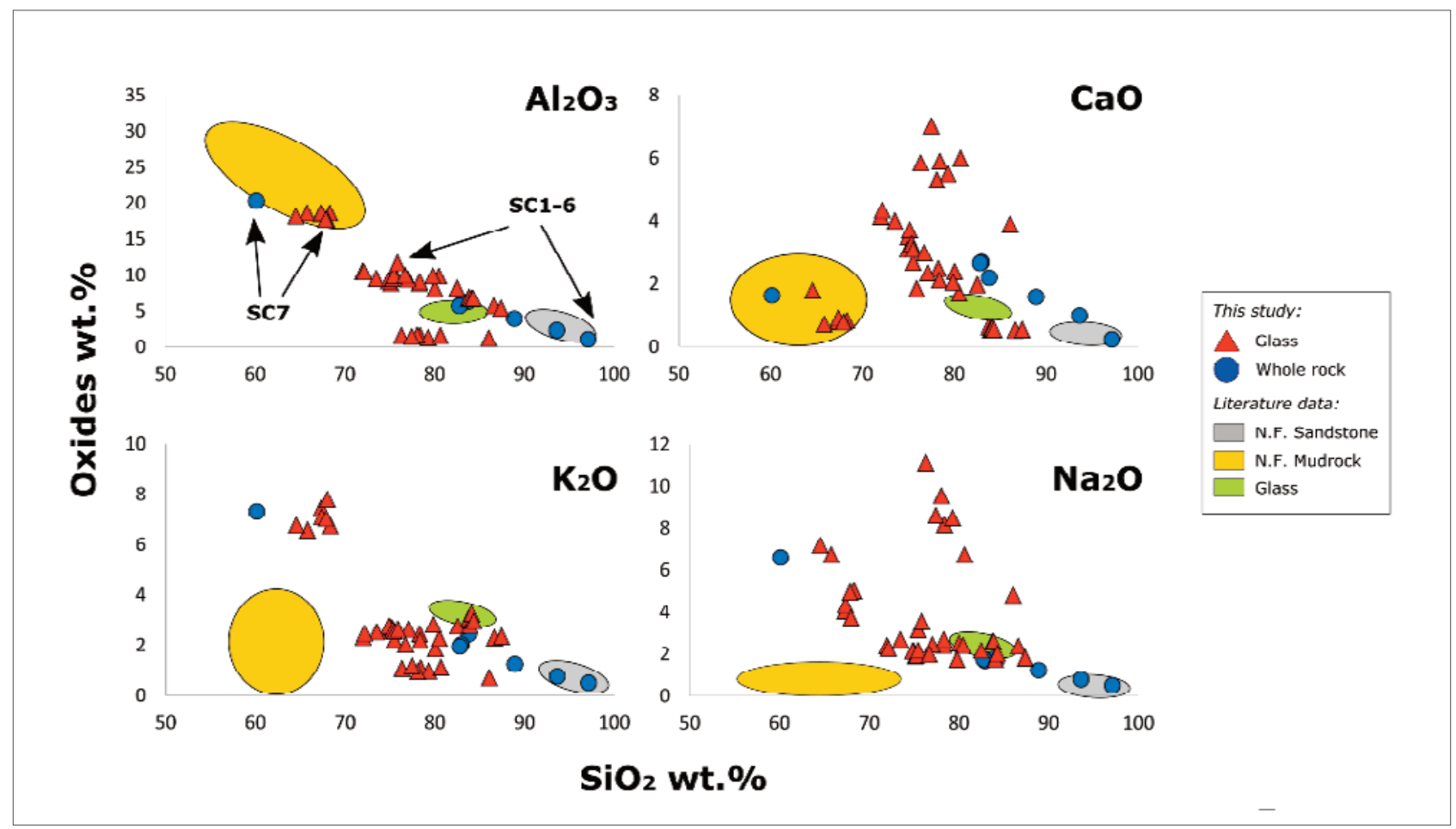

FIGURE 8. Whole rock and interstitial melt compositions of the investigated xenoliths compared to literature data of Numidian Flysch sandstone and mudrock [Barbera et al., 2014] and interstitial melt in Etnean quartzarenitic xenolith investigated by Mollo et al., 2017. Black arrows indicate the compositional ranges of whole rock xenoliths and their glass for SC1-6 samples and SC7 xenolith which shows a marked compositional difference. 

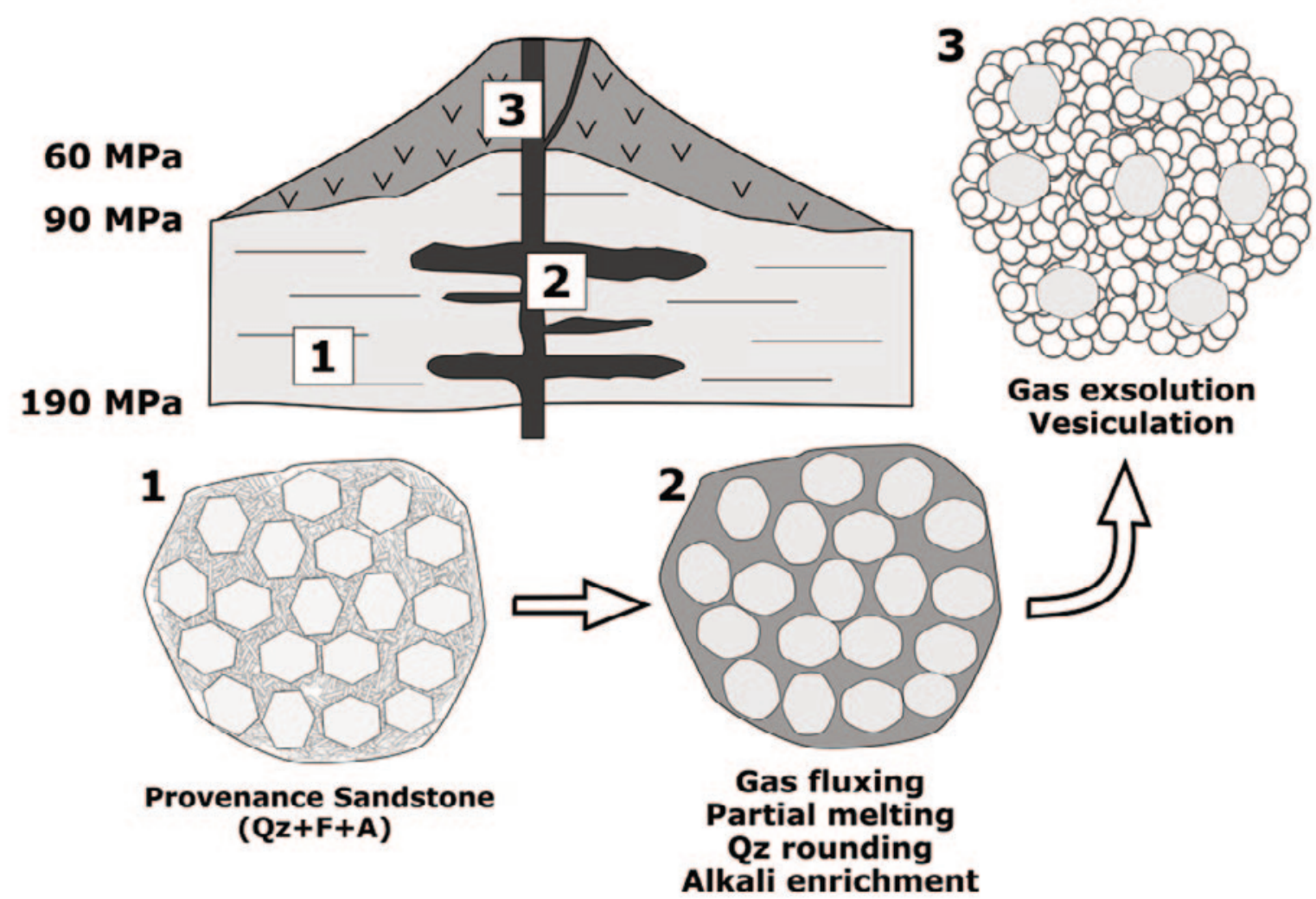

FIGURE 9. Schematic illustration (not in scale) of the main steps of textural evolution of xenoliths: 1) parental sandstone made of quartz grains (Qz), feldspars (F) and accessory minerals (A); 2) tearing off of the xenoliths, partial melting of the F+A minerals, rounding of quartz grains and alkali enrichment by gas fluxing; 3) magma transport to the shallow plumbing system $(\mathrm{P}<60 \mathrm{MPa})$, gas exsolution and massive vesiculation. Pressure values are referred as beneath the summit craters.

ing of solidified rocks stored in the shallow levels of the Etnean plumbing system. Here we propose that a similar process could affect portions of the sedimentary basement, either immediately before or after their incorporation in the uprising magmas. Gas fluxing of the xenoliths would therefore trigger the partial melting, hydrate the formed melt and explain some peculiar features of the SC7 sample.

In fact, this rock significantly differs from the other xenoliths, since it is given by a foamy structure with millimetric bubbles and rare small grains of quartz or lithic fragments. The whole rock composition matches that of the mudrocks constituting the lower portion of the $\mathrm{Nu}$ midian Flysch units (Figure 8). Rocks belonging to these stratigraphic successions show variegate composition, with presence of quartz ( $5-44$ vol.\%), feldspar (3 -14 vol.\%) and clay minerals (60-90 vol.\%), which are mostly given by kaolinite (up to 48 vol.\%). Detailed compositions are reported by Barbera et al., [2009; 2014]. Spot analysis on the glass phase indicate that also the interstitial glass falls in the mudrock field (Figure 8). These features, together with the peculiar texture of the SC7 sample, indicate that a teared off fragment of mudrock underwent almost total melting and developed an intense vesiculation during the upraise through the plumbing system, with vesicles grown up to the millimetric scale. For this particular case, the origin of the gas phase triggering the vesiculation could be related to the breakdown of the hydrate kaolinite constituting the clayous part of the sediments. However, we cannot rule out the influence of gas fluxing, since the mineralogical composition of the parental rock remains unknown and the sample shows a high content of $\mathrm{Na}$ and $\mathrm{K}$ that cannot be related to the mudrocks of the Numidian Flysch. In fact, although these two elements are relatively scarce in the Numidian Flysches (see Figure 8) they can be carried by magmatic gases and eventually enrich magmatic melts located in shallow zones of the Etnean plumbing system, as widely discussed by Ferlito et al. [2008, 2009] and Ferlito and Lanzafame [2010]. Here, we propose that this process could be most likely responsible also for the Alkali enrichment in the SC7 xenolith. 
Despite the fact it was almost entirely melted as suggested by the foam-like structure, this rock was not assimilated by the hosting magma. The reason of this strange occurrence remains unknown and we speculate that for this rock the entire process from detachment from the basement and emission in the atmosphere occurred in a very short span of time, which did not lead to a complete disruption of the sample.

\section{CONCLUSIONS}

The results of this study strengthen the idea that the sedimentary basement beneath Mount Etna volcano, constituted by at least two lithologies, provided the rocks of quartzarenitic SC1-SC6 and mudrock SC7 xenoliths. The source of this crustal material can be identified in the quartzarenites and mudrocks composing the Numidian Flysch. Mineralogical and textural features of the xenoliths coupled with chemical investigations indicate that parental rocks, detached from the basement and carried up through the Etnean feeding system by rising magmas, undergo textural and chemical modifications strongly altering their original structure. The most intriguing features of the samples can be summarized as: i) the dual origin of the xenoliths (quartzarenites and mudrock); ii) the presence of highly vesiculated glass; iii) the rarity of grains in the mudrock xenolith, which also shows a foamy structure with vesicles up to $5 \mathrm{~mm}$ in size, and iv) the anomalous enrichment in Alkali with respect of the parental rocks. All these characteristics can be well explained by a multistep process of partial melting - gas fluxing - alkali enrichment - vesiculation which shaped the final structure, mineralogy and texture of the xenoliths (Figure 9). This model confirms the idea that at Mount Etna a key-role is played by the gas phase (mostly $\mathrm{H} 2 \mathrm{O}$ and C02) through the feeding system, able to hydrate and alter the chemical composition of both crustal and magmatic materials. Finally, this study highlights the importance of the multiscale approach when investigating geological samples such as xenoliths. Using 3D images collected at different pixel size allowed us to describe adequately the variations of textures at different scales. Combining image analysis with chemical investigations on the sample components (grains and glass) was demonstrated to be a powerful tool to formulate a model for describing their history from the detachment of sedimentary portions belonging to the basement to the emission in the atmosphere as xenoliths embedded in lavas.
Acknowledgements. We appreciate the constructive comments of W. Bohrson and an anonymous reviewer. We are also thankful to Noè Caruso for his help with English text.

\section{REFERENCES}

Al-Raoush, R. and A. Papadopoulos (2010). Representative elementary volume analysis of porous media using X-ray computed tomography, Powd. Tech. 200, 69-77.

Allard, P., B. Behncke, S. D’Amico, M. Neri and S. Gambino (2006). Mount Etna 1993-2005: anatomy of an evolving eruptive cycle, Earth Sci. Rev. 78, 85-114.

Andronico, D., S. Branca, S. Calvari, M. Burton, T. Caltabiano, R.A. Corsaro, P. Del Carlo, G. Garfi, L. Lodato, L. Miraglia, F. Murè, M. Neri, E. Pecora, M. Pompilio, G. Salerno, L. Spampinato (2005). A multi-disciplinary study of the 2002-03 Etna eruption: insights into a complex plumbing system. Bull. Volcan. 67, 314-330.

Arzilli, F., L. Mancini, M. Voltolini, M. R. Cicconi, S. Mohammadi, G. Giuli, D. Mainprice, E. Paris, F. Barou and M. R. Carroll (2015). Near-liquidus growth of feldspar spherulites in trachytic melts: 3D morphologies and implications in crystallization mechanisms, Lithos, 216-217, 93-105.

Baker, D.R., L. Mancini, M. Polacci, M.D. Higgins, G.A.R Gualda, R.J. Hill and M.L. Rivers (2012a). An introduction to the application of X-ray microtomography to the three-dimensional study of igneous rocks, Lithos 148, 262-276.

Baker D.R, F. Brun, C. O'Shaughnessy, L. Mancini, J. L. Fife and M.L. Rivers (2012b). A four-dimensional X-ray tomographic microscopy study of bubble growth in basaltic foam. Nat. Comm., 3, 1135, doi:10.1038/ncomms2134

Barbera, G., A. Lo Giudice, P. Mazzoneli and A. Pappalardo (2009). Combined statistical and petrological analysis of provenance and diagenetic history of mudrocks: Application to Alpine Tethydes shales (Sicily, Italy). Sedim. Geol., 213, 27-40.

Barbera, G., G. Barone, P. Mazzoleni, D. Puglisi, H.M. Khozyem and 0. Mashaly (2014). Mineralogy and Geochemistry of the Numidian Formation (CentralNorthern Sicily): intra-formation variability and provenance evaluation. Ital. J. Geosci. (Boll. Soc. Geol. It.), 133(1), 13-26, doi: 10.3301/IJG.2013.07

Behncke, B. and M. Neri (2003). The July-August 2001 eruption of Mt. Etna (Sicily), Bull. Volcan., 65(7), 
461-476.

Ben Avraham, Z. and M. Grasso (1990). Collisional zone segmentation in Sicily and surrounding areas in the central Mediterranean. Ann. Tecton. 4, 131-139.

Branca, S. and V. Ferrara (2013). The morphostructural setting of Mount Etna sedimentary basement (Italy): Implications for the geometry and volume of the volcano and its flank instability, Tectonophys. 586, 46-64, doi: 10.1016/j.tecto.2012.11.011.

Branca, S., M. Coltelli, G. Groppelli and F. Lentini (2011). Geological map of Etna volcano, 1:50,000 scale. Ital. J. Geosci. 130(3), 265-291. doi: http://dx.doi.org/10.3301/IJG.2011.15.

Brun F, Dreossi, D. (2010) Efficient curve-skeleton computation for the analysis of biomedical 3D images, Biomedical Sciences Instrumentation, Vol. 46, pp. 475-80, 2010.

Brun, F., L. Mancini, P. Kasae, S. Favretto, D. Dreossi and G. Tromba (2010). Pore3D: a software library for quantitative analysis of porous media. Nucl. Instrum. Method. A, 615, 326-332.

Brun, F., A. Accardo, G. Kourousias, D. Dreossi and R. Pugliese (2013). Effective implementation of ring artifacts removal filters for synchrotron radiation microtomographic images. Proc. Int. Symp. Im. and Sign. Process. Analys., ISPA, 672-676.

Brun, F., L. Massimi, M. Fratini, D. Dreossi, F. Billé, A. Accardo, R. Pugliese and A. Cedola (2017). SYRMEP Tomo Project: a graphical user interface for customizing CT reconstruction workflows. Adv. Struct. Chem. Imag. 3(1), 4.

Burollet, P.F., J. M. Mugniot and P. Sweeney (1978). The Geology of the Pelagian Block: The Margins and Basins off Southern Tunisia and Tripolitania, in: The Ocean Basins and Margins Nairn, A.E.M., W. H. Kanes and F.G. Stehli (Editors) Springer, Boston, MA.

Clocchiatti, R., Joron, J.L., Treuil, M., 1988. The role of selective alkali contamination in the evolution of recent historical lavas of Mt. Etna. Journal of Volcanology and Geothermal Research 34, 241-249.

Clocchiatti, R., M. Condomines, N. Guénot and J. C. Tanguy (2004). Magma changes at Mount Etna: the 2001 and 2002-2003 eruptions, Earth Plan. Sci. Lett. 226, 397-414.

Coltelli, M., P. Del Carlo and L. Vezzoli (2000). Stratigraphic constrains for explosive activity in the last 100 ka at Etna Volcano, Italy, Int. J. Earth Sci. 89, 665-677.
Condomines, M., J.C. Tanguy and V. Michaud (1995). Magma dynamics at Mt Etna: constraints from U$\mathrm{Th}-\mathrm{Ra}-\mathrm{Pb}$ radioactive disequilibria and $\mathrm{Sr}$ isotopes in historical lavas, Earth Plan. Sci. Lett. 132, 25-41.

Corsaro, R.A. and M. Pompilio (2004). Dynamics of magmas at Mount Etna, in: Mt. Etna: volcano laboratory A. Bonaccorso, S. Calvari, M. Coltelli, C. Del Negro and S. Falsaperla (Editors), American Geophysical Union, Geophysical Monograph 143, 91-110.

Corsaro, R.A., L. Miraglia and M. Pompilio (2007). Petrologic evidence of a complex plumbing system feeding the July-August 2001 eruption of Mt. Etna, Sicily, Italy. Bull. Volcan. 69, 401-421.

Costanza-Robinson, M.S., Estabrook, B.D., Fouhey, D.F. 2011. Representative elementary volume estimation for porosity, moisture saturation, and air-water interfacial areas in unsaturated porous media: Data quality implications, Water Res. Res. 47, W07513, doi:10.1029/2010WR009655.

Dewey, J.F., M. L. Helman, E. Turco, D. H. W. Hutton and S.D. Knott (1989). Kinematics of the western Mediterranean, in Alpine Tectonics M.P. Coward, D. Dietrich and R.G. Park (Editors), Geological Society, London, Special Publications 45, 265-283.

D’Errico, M., A. Di Staso, A. Fornelli, D. Guida, F. Micheletti, V. Perrone and G. Raffaelli (2014). The Numidian Flysch: A guide formation for the reconstruction of the paleogeography and tectono-sedimentary evolution of southern Apennines, Bull. Soc. Geol. Fran., 185(5), 343-356.

De Beni, E., S. Branca, M. Coltelli, G. Groppelli and J. Wijbrans, (2011). ${ }^{39} \mathrm{Ar} /{ }^{40} \mathrm{Ar}$ isotopic dating of Etna volcanic succession, It. J. Geosci. 130 (3), 292-305 http://dx.doi.org/10.3301/IJG.2011.14.

Dongarra, G. and P. Ferla (1982). Le argille di Portella Colla e del flysch numidico auct. (M. Madonie - Sicilia). Aspetti deposizionali e diagenetici, Rend. Soc. It. Mineral. Petrol., 38(3), 1119-1133.

Ferla, P., P. M. Nuccio and M. Valenza (1978). Thermochemical phenomena in the interaction between magma and arenaceous xenoliths in the 1886 Mount Etna lava, Mineral. Petr. Acta, 22, 71-84.

Ferlito, C., M. Viccaro and R. Cristofolini (2008). Volatile induced differentiation in the plumbing system of Mt. Etna volcano (Italy): evidence from glass tephra of the 2001 eruption, Bull. Volcan. 70(4), 455-473.

Ferlito, C., M. Coltorti, R. Cristofolini and P. P. Giacomoni (2009). The contemporaneous emission of low-K and high-K trachybasalts and the role of the NE rift 
during the 2002 eruptive event, Mt. Etna, Italy, Bull. Volcan. 71(5), 575-587.

Ferlito, C. and G. Lanzafame (2010). The role of supercritical fluids in the potassium enrichment of magmas at Mount Etna volcano (Italy), Lithos, 119, 642-650.

Ferlito, C., M. Coltorti, G. Lanzafame and P. P. Giacomoni (2014). The volatile flushing triggers eruptions at open conduit volcanoes: Evidence from Mount Etna volcano (Italy), Lithos, 184-187, 447-455

Ferlito, C., V. Bruno, G. Salerno, T. Caltabiano, D. Scandura, M. Mattia, M. Coltorti (2017). Dome-like behaviour at Mt. Etna: The case of the 28 December 2014 South East Crater paroxysm, Sci. Rep., 7(1), 5361.

Ferlito, C., (2018). Mount Etna. Just a giant hot spring!, Earth-Sci. Rev. 177, 14-23.

Finetti, I.R., F. Lentini, S. Carbone, A. Del Ben, A. Di Stefano, E. Forlin, P. Guarnieri, M. Pipan and A. Prizzon (2005). Geological outline of Sicily and Lithospheric tectonodynamics of its Tyrrhenian margin from new CROP seismic data. In: CROP, Deep Seismic Exploration of the Mediterranean Region I. R. Finetti (Editor), Elsevier, 319-376.

Franzini, M. and L. Leoni (1972). A full matrix correction in X-ray fluorescence analysis of rock samples, Atti Soc. Tosc. Sci. Nat. Mem., A79, 7-22.

Germanique, J.C. (1994). Major, trace and rare-earth elements in fourteen gsj reference samples Determination by X-ray fluorescence spectrometry and inductively coupled plasma optical emission spectrometry, Geosc. Newslet., 18, 91-100.

Gitman, I.M., H. Askes and L.J. Sluys (2007). Representative volume: Existence and size determination, Eng. Fract. Mech., 74(16), 2518-2534.

Grasso, M. and F. Lentini (1982). Sedimentary and tectonic evolution of the eastern hyblean plateau (Southeastern Sicily) during late cretaceous to quaternary time, Palaeogeo. Palaeoclim. Palaeoec., 39, $261-280$.

Heap M.J., S. Mollo, S. Vinciguerra, Y. Lavallée, K.U. Hess, D.B. Dingwell, P. Baud, G. Iezzi (2013). Thermal weakening of the carbonate basement under Mt. Etna volcano (Italy): Implications for volcano instability. J. Volcanol. Geoth. Res. 250, 42-60.

Joron, J.L. and M. Treuil, (1984). Etude géochimique et pétrogenése des laves e l'Etna, Sicilie, Italie, Bull. Volcan. 47(4), 1125-1144.

Lak, M., D. Néraudeau, A. Nel, P. Cloetens, V. Perrichot and
P. Tafforeau (2008). Phase contrast X-ray synchrotron imaging: opening access to fossil inclusions in opaque amber, Microsc. Microan. 14, 251259.

Lanzafame, G., G. Iezzi, G., L., Mancini, F. Lezzi, S. Mollo, C. Ferlito (2017). Solidification and Turbulence (Non-laminar) during Magma Ascent: Insights from 2D and 3D Analyses of Bubbles and Minerals in an Etnean Dyke, J. Petrol., 58-8, 1511-1534, doi: 10.1093/petrology/egx063

Lentini F. (1982). The geology of the Mt. Etna basement. Mem. Soc. Geol. Ital. 23, 7-25 XXIII.

Lentini F. and L. Vezzani (1978). Tentativo di elaborazione di uno schema strutturale della Sicilia orientale, Mem Soc. Geol It. 19, 495-500.

Lentini, F., S. Carbone, S. Catalano and M. Grasso (1996). Elementi per la ricostruzione del quadro strutturale della Sicilia orientale, Mem. Soc. Geol. It. 51, 17.

Lentini, F., S. Carbone and P. Guarnieri (2006). Collisional and postcollisional tectonics of the ApenninicMaghrebian orogen (southern Italy), in: Postcollisional tectonics and magmatism in the Mediterranean region and Asia Y. Dilek and S. Pavlides (Editors), GSA Special Paper, 409, 57-81.

Maire, E. and P. J. Withers (2014). Quantitative X-ray tomography, Int. Mat. Rev. 59, 1-43.

Marty, B., T. Trull, P. Lussiez, I. Basile, J. C. Tanguy, (1994). He, Ar, O, Sr and Nd isotope constraints on the origin and evolution of Mount Etna magmatism, Earth Plan. Sci. Lett. 126, 29-39.

Michaud, V. (1995). Crustal xenoliths in recent hawaiites from Mount Etna, Italy: evidence for alkali exchanges during magma-wall rock interaction. Chem. Geol. 122, 21-42.

Mollo, S., G. Lanzafame, M. Masotta, G. Iezzi, C. Ferlito and P. Scarlato (2011). Cooling history of a dyke as revealed by mineral chemistry: a case study from Mt. Etna volcano, Chem. Geol. 288, 39-52.

Mollo S., J. D. Blundy, P. P. Giacomoni, M. Nazzari, P. Scarlato, M. Coltorti, A. Langone and D. Andronico (2017). Clinopyroxene-melt element partitioning during interaction between trachybasaltic magma and siliceous crust: Clues from quartzite enclaves at Mt. Etna volcano. Lithos, 284-285, 447-461, doi: 10.1016/j.lithos.2017.05.003.

Monaco, C., S. Catalano, O. Cocina, G. De Guidi, C. Ferlito, S. Gresta, C. Musumeci, and L. Tortorici (2005), Tectonic control on the eruptive dynamics at Mt. Etna volcano (eastern Sicily) during the 2001 and 
2002-2003 eruptions, J. Volcanol. Geotherm. Res., 144, 221-233.

Newman, S. and J. B. Lowenstern (2002). VOLATILECALC: a silicate melt-H2O CO2 solution model written in Visual Basic for excel, Comp. Geosci., 28(5), 597-604.

Ogniben, L. (1966). Nota illustrativa dello schema geologico della Sicilia nord-orientale, Riv. Min. Sic. 6465, 184212.

Paganin, D., S. C. Mayo, T. E. Gureyev, P. R. Miller and S. W. Wilkins (2002). Simultaneous phase and amplitude extraction from a single defocused image of a homogeneous object, J. Microsc., 206, 33-40.

Pedley, H.M. and M. Grasso (1992). Miocene syntectonic sedimentation along the western margins of the Hyblean-Malta platform: a guide to plate margin processes in the central Mediterranean. J. Geodyn. 15, 19-37.

Polacci, M., L. Mancini and D.R. Baker (2010). The contribution of synchrotron X-ray computed microtomography to understanding volcanic processes, J. Synchr. Rad. 17, 215-221.

Pinter, P.R., R. W. H. Butler, A. J. Hartley, R. Maniscalco, N. Baldassini and A. Di Stefano (2016). The Numidian of Sicily revisited: a thrust-influenced confined turbidite system, Mar. Petrol. Geol., 78, 291311.

Pompilio, M., A. Bertagnini, P. Del Carlo and A. Di Roberto (2017). Magma dynamics within a basaltic conduit revealed by textural and compositional features of erupted ash: The December 2015 Mt. Etna paroxysms, Sci. Rep., 7(1), 4805.

Tanguy, J.C. M. Condomines and G. Kieffer (1997). Evolution of the Mount Etna magma: constraints on the present feeding system and eruptive mechanism. J. Volcan. Geotherm. Res. 75, 221-250.

Tibaldi, A. and G. Groppelli (2002). Volcano-tectonic activity along structures of the unstable NE flank of Mt. Etna (Italy) and their possible origin, J. Volcan. Geotherm. Res., 115, 277-302.

Thomas, M.F.H. (2011). Sedimentology and basin context of the Numidian Flysch Formation; Sicily and Tunisia, PhD Thesis, The University of Manchester, School of Earth, Atmospheric and Environmental Sciences.

Tomasi, C. and R. Manduchi (1998). Bilateral filtering for gray and color images, Sixth Int. Conf. Comp. Vis., New Delhi, India, 839-846.

Tonarini S., P. Armienti, M. D’Orazio, F. Innocenti, M.
Pompilio and R. Petrini (1995). Geochemical and isotopic monitoring of Mt. Etna 1989-1993 eruptive activity: bearing on the shallow feeding system, J. Volcan. Geotherm. Res., 64(1-2), 95-115.

Viccaro, M., C. Ferlito, L. Cortesogno, R. Cristofolini and L. Gaggero (2006). Magma mixing during the 2001 event at Mount Etna (Italy): effect on the eruptive dynamics, J. Volcan. Geotherm. Res. 149, 139-159.

Viccaro, M., I. Garozzo, A. Cannata, G. Di Grazia and S. Gresta (2014). Gas burst vs. gas-rich magma recharge: A multidisciplinary study to reveal factors controlling triggering of the recent paroxysmal eruptions at Mt. Etna, J. Volcan. Geotherm. Res., 278-279, 1-13.

Yellin-Dror, A., M. Grasso, Z. Ben-Avraham, G. Tibor (1997). The subsidence history of the northern Hyblean plateau margin, southeastern Sicily. Tectonoph. 282, 277-289.

Wezel, F.C. (1969). Lineamenti Sedimentologico Del Flysch Numidico Della Sicilia Nord Orientale, Memo. Inst. Geol. Mineral. Univ. Padova 26, 1-32.

Zandomeneghi, D., M. Voltolini, L. Mancini, F. Brun, D. Dreossi and M. Polacci (2010). Quantitative analysis of X-ray microtomography images of geomaterials: Application to volcanic rocks. Geosph. 6, 793804.

Zambrano, M., E. Tondi, L. Mancini, F. Arzilli, G. Lanzafame, M. Materazzi, S. Torrieri (2017). 3D Porenetwork quantitative analysis in deformed carbonate grainstones, Mar. Petrol. Geol. 82, 251-264. 